\title{
RDUS
}

Revue de DROIT

UNIVERSITÉ DE SHERBROOKE

Titre : $\quad$ FREE MOVEMENT OF GOODS IN THE EUROPEAN COMMUNITY : A CRITIQUE OF THE JURISPRUDENCE ON ARTICLE 30 OF THE TREATY OF ROME

Auteur(s): $\quad$ lan B. LEE

Revue : $\quad$ RDUS, 1993-1994, volume 24, numéro 1

Pages: $\quad 121-153$

ISSN : $\quad 0317-9656$

Éditeur : $\quad$ Université de Sherbrooke. Faculté de droit.

URI : $\quad$ http://hdl.handle.net/11143/13364

DOI : $\quad$ https://doi.org/10.17118/11143/13364 
Page vide laissée intentionnellement. 


\title{
COMMENTAIRE
}

\section{FREE MOVEMENT OF GOODS IN THE EUROPEAN COMMUNITY : A CRITIQUE OF THE JURISPRUDENCE ON ARTICLE 30 OF THE TREATY OF ROME}

\begin{abstract}
par Ian B. LEE*
L'article 30 du Traité de Rome interdit «les restrictions quantitatives à l'importation, ainsi que toutes mesures d'effet équivalent», parmi les États membres de la Communauté européenne. Selon l'auteur, I'interprétation excessivement englobante que la Cour de justice des communautés européennes a donnée à la notion de «mesures d'effet équivalent» entraîne la conclusion que toute législation nationale est susceptible d'entraver le commerce intracommunautaire. L'auteur analyse les fondements théoriques de l'approche véhiculée par la Cour, et affirme que cette approche s'est montrée déficiente dans une quadrilogie d'arrêts dans lesquels on prétendait que des lois relatives à l'observance du dimanche contrevenaient à l'article 30. La Cour a tenté de diminuer la portée de l'article 30 en assouplissant les critères de la dérogation au principe de la libre circulation des marchandises. Toutefois, I'auteur soutient que la Cour ne peut éviter de réviser ses arrêts antérieurs sur l'article 30 et que, dans l'intérêt de la certitude et de la stabilité, la Cour devrait le faire explicitement.
\end{abstract}

Article 30 of the Treaty of Rome prohibits «quantitative restrictions on imports and all measures having equivalent effect», among the Member States of the European Community. The author suggests that the excessively broad interpretation given by the European Court of Justice to the phrase «measures having equivalent effect $\gg$ implies that virtually all national legislation is capable of hindering intra-Community trade. Following a discussion of the theoretical basis for the Court's reasoning, the author maintains that the inadequacy of the Court's approach became evident in a series of recent cases in which Sunday observance legislation was alleged to violate Article 30. The Court has tried to reduce the scope of Article 30 by relaxing the criteria necessary to justify a derogation from the principle of the free movement of goods. However, the author argues that the Court cannot avoid reconsidering its earlier rulings on Article 30, and that, in the interests of certainty and stability, it should do so expressly.

*. $\quad$ LL.B., Université de Toronto. 


\section{TABLE OF CONTENTS}

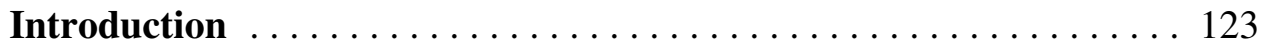

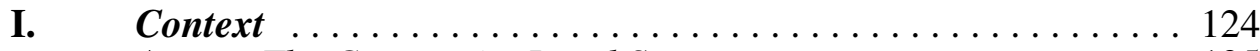

A. The Community Legal System . . . . . . . . . . . . . . 125

B. Structure of the Prohibition against Import Barriers . . . 127

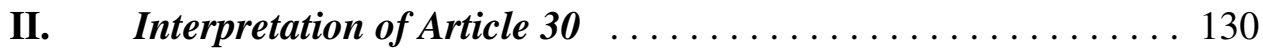

A. Indistinctly Applicable Measures and the Court of

Justice : From Dassonville to Cinéthèque ........... 130

B. Indistinctly Applicable Measures and the Canadian

Common Market . . . . . . . . . . . . . . . . . . . . . 138

C. Article 30 and Harmonization ................ 141

D. The Requirement of Disadvantage ............. 145

III. Sunday Trading .......................... 151

A. The Sunday Trading Cases as a Development of the Cinéthèque Line ....................... 151

B. Revival of the Theory of Disadvantage? .......... 157

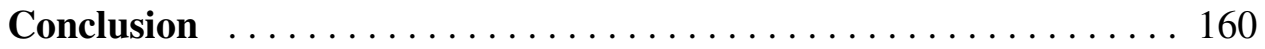




\section{Introduction}

Consider the following scenario. Having seen Edwards Books and Art Ltd. lose its appeal in the Supreme Court of Canada under the Canadian Charter of Rights and Freedoms, another Ontario bookseller decides to challenge the provincial Retail Business Holidays Act under the Constitution Act, 1867. The bookseller's lawyers argue that the obligation to close on Sundays and other public holidays reduces the quantity of books sold from outside the province, and therefore constitutes an unconstitutional infringement on interprovincial trade.

Does this argument seem farfetched? After more than a century of litigation on the division of powers, it is difficult to imagine such an argument being taken seriously today in Canada. There is little doubt that provincial regulation of local businesses is intra vires, regardless of its incidental effects on the pattern of interprovincial trade. ${ }^{1}$

For this reason, Canadians may be surprised to learn that according to the Court of Justice of the European Communities (hereinafter ECJ or Court of Justice), national Sunday closing legislation is an obstacle to the free movement of goods among the Member States of the European Community, and violates the Treaty of Rome unless it can be demonstrated to be a justifiable derogation from the principle.

It will be argued that if the Court of Justice means what it says in the «Sunday Trading cases», ${ }^{2}$ its approach to the free movement of goods is not justified. The fact that the ECJ's analysis in these judgments appears to be based on a credible interpretation of its own jurisprudence serves only to demonstrate that the approach taken to the free movement of goods was defective from the beginning. Indeed, the Court of Justice's early enthusiasm for a broad reading of Article 30, the Treaty's basic provision on import barriers, has come back to haunt the ECJ in the Sunday Trading cases.

This paper analyzes the Court of Justice's approach to Article 30. It begins with a brief look at the context of the provision (Section I). Next the

1. Carnation Co. v. Québec Agricultural Marketing Board, [1968] S.C.R. 238 [hereinafter Carnation]. See also G. Rémillard, Le Fédéralisme canadien, vol. 1 (Montréal : Québec/Amérique, 1983) at 367-68.

2. Case 145/88, Torfaen B.C. v. $B \& Q$ plc, [1990] 1 All E.R. 129 (E.C.J.) [hereinafter Torfaen]; Case C-312/89, Union départementale des syndicats CGT de l'Aisne v. Sidef Conforama, [1991] E.C.R. I-997 [hereinafter Conforama]; Case C-332/89, Criminal Proceedings against Marchandise, [1991] E.C.R. I-1027 [hereinafter Marchandise]; Case C-169/91, Stoke-on-Trent C.C. v. B \& Q plc, [1992] E.C.R. I-6654 [hereinafter Stoke-onTrent]. 
development of the jurisprudence applicable to Article 30 is critically reviewed and the Court of Justice's theory of the role of the Article in the Common Market is measured against other theories (Section II). The final section (III) discusses the application of the ECJ's jurisprudence to the Sunday Trading cases and suggests that the decisions can be defended more easily if the Court of Justice is taken not to mean what it says.

\section{Context}

Although a lively debate is carried on in the literature over whether the European Community (EC) is in the nature of a federation or an international organization, it is sufficient for our purpose to describe the EC as consisting essentially of two elements : a common market, and a collection of institutions devoted to the protection and development of the common market. ${ }^{3}$ By the Treaty of Rome (or EEC Treaty), ${ }^{4}$ signed in 1957, the original Member States created a common market characterized by the free movement of goods, labour and capital within the bloc, and established rules regarding, inter alia, a common external tariff and a common competition policy. ${ }^{5}$ The free movement of goods in particular is protected in the Treaty of Rome by a host of provisions prohibiting customs duties and other restrictive measures between the Member States (Articles 9 to 37).

The European Community owes much of its progress towards integration to the institutions which the Member States created to defend and develop the common market. Although the members of the EC are sovereign States, the institutional framework they created has some characteristics of a federation, including an autonomous legal system and a Court of Justice. ${ }^{6}$ Because of an effective institutional enforcement mechanism, Articles 9 to 37 are a powerful weapon against protectionism on the part of Member States.

3. For general information on the European Community, see J. Steiner, Textbook on EEC Law, 2d ed. (London : Blackstone, 1990).

4. Treaty Establishing the European Economic Community (Rome, 25 March 1957).

5. Two other treaties created common markets in specific products. The name «European Community» includes the common markets and institutions of all three treaties, which have since been merged.

6. The newest reforms to the EC, contained in the Treaty of Maastricht, include significant modifications to the institutional framework as well as a Social Policy Agreement and a number of non-justiciable legal principles and political commitments. However, the amendments should not affect the operation of Article 30 of the EEC Treaty or the role of the ECJ in interpreting it. See further D. Curtin, «The Constitutional Structure of the Union: A Europe of Bits and Pieces» (1993) 30 C.M.L.Rev. 17. 


\section{A. The Community Legal System}

At the centre of the enforcement mechanism are the «twin pillars» of the Community legal system, namely the direct applicability and primacy of Community law. ${ }^{7}$ The principle of direct applicability means that the Treaty creates rights which individuals and enterprises can assert in their national courts. In particular, Articles 30 to 34, dealing with non-tariff barriers within the Community, have had direct effect as of the end of the «transition period». ${ }^{8}$ Thus, unlike the Canada-U.S. Free Trade Agreement or the General Agreement on Tariffs and Trade, the EEC Treaty «has created its own legal system which ... [is] an integral part of the legal systems of the Member States and which their courts are bound to apply.» ${ }^{9}$ In this way, the implementation of the norms of the Common Market cannot be thwarted as easily by States refusing for political reasons to pursue claims on behalf of their nationals.

The second «pillar» is the principle that Community law prevails over the national law of the Member States. Even in international law generally, the failure to comply with a treaty is not justifiable on the grounds of a conflict with the obligor State's domestic law. ${ }^{10}$ When this principle is combined with direct applicability, the result is that individuals have access to (national) courts which can decline to apply national law to the extent that it conflicts with Community law.

Since a domestic court's authority to set aside national law is itself granted by national law - for example, the domestic legislation implementing the EEC Treaty - the principle of supremacy is more fragile than it may appear. In the United Kingdom, for example, the constitutional principle of parliamentary sovereignty means that Parliament is incapable of alienating its right to pass legislation inconsistent with the EEC Treaty. ${ }^{11}$ Nevertheless, even in the U.K., the House of Lords has indicated that courts should «construe» national legislation so as to conform to Community law, «no matter how wide a departure from the prima facie meaning may be needed.» ${ }^{12}$

7. D. Wyatt and A. Dashwood, The Substantive Law of the EEC (London : Sweet \& Maxwell, 1980) at 26 [hereinafter Wyatt and Dashwood].

8. Case 74/76, Iannelli v. Meroni, [1977] E.C.R. 557 at 575-76; L. Defalque and G. Vandersanden, «La notion de mesure d'effet équivalant à une restriction quantitative (art. 30 du Traité C.E.E.)» (1984) 103 J. des Trib. 489 at 490.

9. Case 6/64, Costa v. ENEL, [1964] E.C.R. 1141 at 1158, [1964] C.M.L.R. 425.

10. Vienna Convention on the Law of Treaties 1969, Article 27. See also Wyatt and Dashwood, supra, note 7 at 28.

11. By the English doctrine of implied repeal (lex posterior derogat priori), any inconsistent subsequent legislation is deemed to have impliedly repealed the previous legislation. See Ellen Street Estates v. Minister of Health, [1934] K.B. 590; O.H. Phillips and P. Jackson, Constitutional and Administrative Law, 7th ed. (London: Sweet \& Maxwell, 1987) at 71-74.

12. Garland v. British Rail Engineering, [1983] 2 A.C. 751, per Lord Diplock. 
It seems that as a practical matter, if national courts are to be expected to go along with the «primacy» of Community law, it is important for these laws, including decisions of the Court of Justice, to be perceived as legitimate. The ECJ in particular must, in interpreting the Treaty, render reasoned decisions based on the effective implementation of the Treaty, and not on extraneous concerns which are properly matters for the national jurisdiction. ${ }^{13}$

\section{B. Structure of the Prohibition against Import Barriers}

At issue in the Sunday Trading cases was the interpretation of Article 30, which provides a broadly worded prohibition on non-tariff import barriers between Member States. The English version ${ }^{14}$ of Article 30 reads as follows :

«Quantitative restrictions on imports and all measures having equivalent effect shall, without prejudice to the following provisions, be prohibited between Member States.»

The «following provisions» referred to in Article 30 relate in particular to a transition period, since elapsed, for the gradual elimination of quantitative restrictions. In addition, Article 34 contains a provision identical to Article 30 except that it applies to restrictions on exports.

Article 30 binds Member States and their agents, as well as the institutions of the Community, ${ }^{15}$ and applies to trade in "goods», which are «products which can be valued in money and which are capable, as such, of forming the subject of commercial transactions.» ${ }^{16}$

Derogation from the principle of the free movement of goods is authorized by Article 36 on certain enumerated grounds. Article 36 reads as follows :

13. See L. Gormley, Case Comment on Torfaen Borough Council v. B \& $Q$ plc (1990) 27 C.M.L. Rev. 141; J. Steiner, «Drawing the Line : Uses and Abuses of Article 30 EEC» (1992) 29 C.M.L. Rev. 749 at 750 (text accompanying note 10).

14. The nine versions of the Treaty of Rome, each in a different national language, are equally authentic. See M. Hilf, «The Role of Comparative Law in the Jurisprudence of the Court of Justice of the European Communities» in A. de Mestral et al., eds., The Limitation of Human Rights in Comparative Constitutional Law (Cowansville : Yvon Blais, 1986) at 566.

15. See P. Oliver, Free Movement of Goods in the EEC, 2d ed. (London : European Law Centre, $1988)$ at $38-56$.

16. Case 7/68, Commission v. Italy, [1968] E.C.R. 617 at 626, [1969] C.M.L.R. 1 at 8. It is not necesary for our purposes to investigate in greater detail the limits of the concept of goods. For a review of the issues, the reader is referred to Oliver, supra, note 15 at ch. 2, or to A. Mattera, «Libre circulation des marchandises et articles 30 à 36 du Traité C.E.E.» [1976] R.M.C. 500 at 501-502. 
«The provisions of Articles 30 to 34 shall not preclude prohibitions or restrictions on imports, exports or goods in transit justified on grounds of public morality, public policy [ordre public] or public security; the protection of health and life of humans, animals or plants; the protection of national treasures possessing artistic, historic or archaeological value; or the protection of industrial and commercial property. Such prohibitions or restrictions shall not, however, constitute a means of arbitrary discrimination or a disguised restriction on trade between Member States.»

The implications of Article 36 will be discussed in greater detail below. At this point, it is sufficient to note that the analysis of a provision of national legislation challenged as an import restriction is a two-stage process. First, it must be shown that the provision is a quantitative restriction on imports or that it has an effect equivalent to a quantitative restriction. If the measure is demonstrated to have a restrictive effect on imports within the meaning of Article 30, it is incompatible with the Treaty unless it is justified under Article 36.

A two-stage approach has of course also been adopted in Canada for the scrutiny of legislation for conformity with the Charter, ${ }^{17}$ and is common in constitutions and human rights instruments, notably the European Convention on Human Rights. ${ }^{18}$ As a corollary of the theory that fundamental documents should be given a large and liberal interpretation, provisions containing derogations are usually interpreted narrowly. In principle, therefore, if a measure prima facie violates the free movement of goods, the standard of justification is strict; accordingly, Article 36 receives a narrow construction. ${ }^{19}$

However, the Canadian experience with section 1 of the Charter has shown that in some cases the legislature is not held to the stringent standard. ${ }^{20}$ Although in the context of the Charter this relaxation of the justificatory standard is often meant to free the legislature to enact laws to protect vulnerable groups, for example, a more pragmatic explanation can also be advanced. An unduly «expansive» interpretation of the so-called substantive provisions of the

17. Canadian Charter of Rights and Freedoms, Part I of the Constitution Act, 1982, being Schedule B of the Canada Act, 1982 (U.K.), c. 11 [hereinafter the «Charter»].

18. Convention for the Protection of Human Rights and Fundamental Freedoms (1950) 213 U.N.T.S. 222. See further the survey of Deschênes J. in «Le rôle du droit comparé dans l'évolution récente des droits de la personne au Canada» in de Mestral et al., supra, note 14 at 590 .

19. Commission v. Italy, supra, note 16.

20. See C. Rogerson, «Section One of the Charter» (unpublished, May 1991), and the cases cited therein, especially R. v. Edwards Books, [1986] 2 S.C.R. 713, Irwin Toy v. Québec (A.G.), [1989] 1 S.C.R. 927, R. v. Keegstra, [1990] 3 S.C.R. 697, and McKinney v. University of Guelph, [1990] 3 S.C.R. 229. 
Charter will often make it appropriate to adopt an analysis under section 1 which is more deferential towards the State. In other words, an interpretation of the rights-conferring provision which «overshoot[s] the actual purpose of the right or freedom in question» would compel the court to expand the derogation in section 1 of the Charter. ${ }^{21}$

Thus, the challenge facing the European Court of Justice in interpreting Article 30 is as follows : if the derogations are to be interpreted restrictively, then the Court of Justice should ensure that whenever a measure is held to be inconsistent with Article 30, it truly does conflict with a fundamental principle of the Common Market so that it can be held to a strict standard of justification. Unfortunately, the Court of Justice has attempted to maintain, simultaneously, an excessively broad interpretation of Article 30 and an extremely narrow interpretation of the derogation contained in Article 36, while rendering decisions which are acceptable, in the result, to the Member States. It is respectfully submitted that this attempt to please everyone has been made at the expense of logic and certainty, especially in the treatment of so-called indistinctly applicable measures.

\section{Interpretation of Article 30}

\section{A. Indistinctly Applicable Measures and the Court of Justice : From Dassonville to Cinéthèque}

A measure is indistinctly applicable if it does not distinguish between national and imported products. Thus, for example, a rule on the «dry matter content» of bread marketed in a Member State is indistinctly applicable, ${ }^{22}$ while a regulation imposing a product standard only on bread imported from another Member State is not.

It is true that the text of Article 30 does not expressly categorize measures as distinctly or indistinctly applicable. Nevertheless, while there is general support for the proposition that measures which are distinctly applicable are banned by Article 30, there is less agreement on the status of indistinctly applicable measures.

21. R. v. Big M Drug Mart, [1985] 1 S.C.R. 295 at 344. See K. Mahoney, «R. v. Keegstra: A Rationale for Regulating Pornography?» (1992) 37 McGill L.J. 242 at 250. For a recent judicial application of what Wilson J. refers to as «a serious and non-trivial approach» to the rights-conferring provisions of the Charter, see Lavigne v. OPSEU, [1991] 2 S.C.R. 211 at 259-60, per Wilson J; $R$. v. Committee for the Commonwealth of Canada, [1991] 1 S.C.R. 139 at 232-33, per McLachlin J.

22. Case 130/80, Fabriek voor Hoogwaardige Voedingsprodukten Kelderman B.V., [1981] E.C.R. 527. 
For example, despite the Commission of the European Communities' pronouncement in 1970 that indistinctly applicable measures were not inconsistent with the free movement of goods unless they had a disproportionate effect on imports, ${ }^{23}$ the Court of Justice settled in 1974 on a broad formulation according to which the indistinctly applicable character of a measure is irrelevant to whether it is «measure having equivalent effect».

The Court of Justice's formulation, set out in Procureur $d u$ Roi v. Dassonville, has become the classic definition of the measures envisaged by Article 30 :

«All trading rules ... which are capable of hindering, directly or indirectly, actually or potentially, intra-Community trade are to be considered as measures having an effect equivalent to quantitative restrictions. ${ }^{24} \gg$

This definition is capable of a very wide scope. In the first place, «trading rule», or «réglementation commerciale» in the French version, includes any regulation of business, not merely international trade regulation. Indeed, the language of Article 30 supports the view that government economic activity other than business regulation is also capable of constituting «measures having an effect equivalent to quantitative restrictions». ${ }^{25}$ Moreover, it is unnecessary that a measure be distinctly applicable or even that it protect domestic producers for it to be «capable of hindering» (or «susceptible d'entraver») the flow of goods across boundaries within the Community. By a literal reading of the strongly worded test in Dassonville, all that is necessary is that the presence of the measure be capable of leading to a reduction in imports.

Admittedly, this was not the only possible interpretation of Dassonville. It would not be unreasonable to read «capable of hindering ... intra-Community trade» as requiring that the measure either be distinctly applicable or have a more severe impact on imports than on domestic products. A broad interpretation of Article 30 was not even necessary to decide the case in Dassonville : the impugned measure was a distinctly applicable measure which imposed a material burden specifically on imported products. Nevertheless, the Court of Justice has subsequently interpreted the Dassonville formulation in a manner consistent with its expansive tone and wording. ${ }^{26}$

23. Directive 70/50, J.O. 1970 L 13/29, Article 3.

24. Case 8/74, [1974] E.C.R. 837 at 852, para. 5 [hereinafter Dassonville].

25. E.L. White, «In Search of the Limits to Article 30 of the EEC Treaty» (1989) 26 C.M.L.Rev. 235 at 235-36. See, for example Case 249/81, Commission v. Ireland, [1982] E.C.R. 4005 [«Buy Irish» campaign].

26. See Steiner, Textbook, supra, note 3 at 72-74 and Oliver, supra, note 15 at 75 et seq., and the authorities cited in those texts. 
It will be recalled that Article 36 permits derogation from Article 30 on certain grounds, namely

«public morality, public policy [ordre public] or public security; the protection of health and life of humans, animals or plants; the protection of national treasures possessing artistic, historic or archaeological value; or the protection of industrial and commercial property...»

It is arguable that if interpreted liberally enough, Article 36 could counteract the broad Dassonville formula. ${ }^{27}$ However, the Court of Justice has severely limited the scope of Article 36, convinced that any measure infringing Article 30 is a violation of a fundamental legal rule of the Community. Accordingly, the Court of Justice has declared the grounds of derogation enumerated in Article 36 to be exhaustive and each of the grounds has received a narrow interpretation. ${ }^{28}$ Thus, many desirable objectives, such as consumer protection and the prevention of unfair competition, have been held to be ineligible. ${ }^{29}$

Moreover, the burden of showing that a measure is saved by Article 36 is on the Member State. ${ }^{30}$ Even if the objective is on the list, the requirement of proportionality means that a measure cannot be justified under Article 36 if another equally effective measure is available which would impair the free movement of goods less, or if the degree of impairment is out of proportion to the objective. ${ }^{31}$

The first major opportunity to reconsider Dassonville came five years after that decision, in the case referred to as Cassis de Dijon. ${ }^{32}$ This case involved a challenge to a regulation on the minimum alcoholic content of fruit liqueurs marketed in Germany. The Court of Justice is not bound by its own past decisions, ${ }^{33}$ and was free to overrule Dassonville by adopting a narrower definition of a hindrance to trade. Alternatively, the Court of Justice could have adopted a more permissive approach to the derogation by overruling its previous

27. This position was advocated, for example, by L. Defalque, «Le concept de discrimination en matière de libre circulation des marchandises» (1987) 23 C.D.E. 471 at 487.

28. Commission v. Italy, supra, note 16; Case 153/78, Commission v. Federal Republic of Germany, [1979] E.C.R. 2555.

29. Case 113/80, Commission v. Ireland, [1981] E.C.R. 1638. See also Defalque, supra, note 27 at 486.

30. Case 251/78, Denkavit Futtermittel v. Minister of Agriculture, [1979] E.C.R. 3369.

31. See, for example, Case 104/75, Officier van Justitie v. De Peijper, [1976] E.C.R. 613 at 635 36.

32. Case 120/78, Rewe-Zentral A.G. v. Bundesmonopolverwaltung für Branntwein, [1979] E.C.R. 649 [hereinafter Cassis de Dijon].

33. See L.N. Brown, The Court of Justice of the European Communities, $3 \mathrm{~d}$ ed. (London : Sweet \& Maxwell, 1989) at 314. 
decisions on Article 36. Instead, however, the decision in Cassis de Dijon muddied the waters because it made no mention of either Dassonville or Article 36. The key passage from the judgment is in the following terms :

«Obstacles to movement within the Community resulting from disparities between the national laws relating to the marketing of the products in question must be accepted in so far as those provisions may be recognised as being necessary in order to satisfy mandatory requirements relating in particular to the effectiveness of fiscal supervision, the protection of public health, the fairness of commercial transactions and the defence of the consumer. ${ }^{34} \gg$

It is now generally accepted that the Court of Justice did not implicitly overrule Dassonville or its Article 36 jurisprudence, and that the judgment instead created a new derogation internal to Article 30 itself. $^{35}$ The new exception was for what the Court of Justice called «mandatory requirements». It is clear from the French term, «exigences impératives», that the derogation is for objectives sufficiently important to justify an infringement of principles fundamental to the Common Market. ${ }^{36}$ Unlike the enumeration in Article 36, the list of exigences impératives is not exhaustive and, as the above excerpt shows, includes a number of legislative objectives which were excluded from Article $36 .{ }^{37}$ Nevertheless, legislation aimed at an exigence impérative remains subject to the same strict test of proportionality as under Article 36 since it derogates from an essential Community principle. ${ }^{38}$

Cassis de Dijon was important because unlike the rule in Dassonville, the impugned product standard in Cassis de Dijon was applicable both to imports and to national products. Despite its indistinct applicability, however, the restriction in Cassis de Dijon was demonstrated to have the effect of protecting a local German industry from a competing French product. ${ }^{39}$

34. Ibid. at paragraph 8 .

35. See P. VerLoren van Themaat, «La libre circulation des marchandises après l'arrêt «Cassis de Dijon»» (1982) 18 C.D.E. 123 at 131-32. There is, however, a school of opinion suggesting that even though Cassis de Dijon does not mention Article 36, in fact the new grounds are merely an illustration of possible Article 36 derogations, possibly falling within «public policy»: see Oliver, supra, note 15 at 92.

36. Cassis de Dijon, supra, note 32 at para. 14.

37. Oliver, supra, note 15 at 87 . Consumer protection and the protection of fair competition are two examples of objectives which qualify as exigences impératives according to the judgment in Cassis de Dijon but which cannot justify a derogation under Article 36 : see note 29, supra.

38. Case 182/84, Proceedings against Miro B.V., [1986] 3 C.M.L.R. 545.

39. The minimum alcoholic content for fruit liqueurs was set to a level low enough that the German product complied but sufficiently high that the rival French product fell short. See Oliver, supra, note 15 at 88. 
As the above excerpt from the judgment suggests, the ECJ chose not to identify the protective character of the regulations as the reason for their unacceptability, indicating instead that the mere existence of non-harmonized national regulations was an obstacle to trade. The Court of Justice further held that to remedy this kind of trade barrier, it is not sufficient for a Member State to treat imported and national products equally; in the absence of harmonization, Article 30 requires the mutual recognition of product standards. The Court of Justice reinforced its point with this observation :

«There is therefore no valid reason why, provided that they have been lawfully produced and marketed in one of the member-States, alcoholic beverages should not be introduced into any other memberState... ${ }^{40} \gg$

For its part, the Commission responded to the judgment by sending the Member States a letter interpreting and reformulating the statement as a positive duty to admit :
«Tout produit importé d'un État membre doit être en principe admis sur le territoire de l'État membre importateur s'il est légalement fabriqué ... et commercialisé sur le territoire [du pays d'exportation $]^{41}{ }^{4} \gg$

These statements caused consternation in some economic circles, ${ }^{42}$ although The Economist viewed the Cassis de Dijon court's emphasis on harmonization and mutual recognition as «a contribution to the great market [that] should be toasted regularly in kir.» ${ }^{43}$

Though the Commission framed the Member State's obligation under Article 30 as a duty to admit, it should be pointed out that the regulation in Cassis de Dijon was technically not a refusal to admit certain products onto the territory of the importing state, since it prohibited neither importation nor production; rather, it was a rule about the characteristics of products marketed on the territory. What the judgment recognizes is that if a product cannot be sold within the territory then imports of the product have been blocked just as effectively as if they had been refused entry at the border. However, the

\footnotetext{
40. Cassis de Dijon, supra, note 32 at para. 14.

41. EC Commission, Communication de la Commission sur les suites de l'arrêt rendu par la Cour de justice des Communautés européennes, le 20 février 1979, dans l'affaire 120-78 (Cassis de Dijon), J.O., C 256, 3 Oct. 1980 at 2, reproduced in [1980] R.M.C. 514.

42. F. Capelli, «Les malentendus provoqués par l'arrêt sur le «Cassis de Dijon»» [1981] R.M.C. 421 at 421.

43. N. Colchester, «A Survey of Europe's Internal Market» supplement to The Economist (9 July 1988) at S7.
} 
(1993) 24 R.D.U.S.

Free Movement of Goods in the European Community :

A critique of the jurisprudence

on Article 30 of the Treaty of Rome

connection between marketing and admission is rarely as clear as it was in Cassis de Dijon, especially when there is no evidence of protective effect or protectionist intent. And in these more ambiguous cases, where a marketing rule merely has an incidental effect on sales of imports, it is not clear why the duty to admit should require the marketing regulation not to be extended equally to imported products.

For example, in the case of a ban on the delivery of baked goods at night (Oebel) or on the serving of strong alcoholic beverages in a hotel (Blesgen), ${ }^{44}$ it was impossible to find either a discriminatory purpose or a disproportionate effect on imports. The Court of Justice decided in these cases that it was not even necessary to refer to exigences impératives, holding simply that each measure had

«... en réalité pas de lien avec l'importation des produits et [n'était]

donc pas de nature à entraver le commerce entre États membres. ${ }^{45}{ }_{\gg}$

The problem with this reasoning is that in Cassis de Dijon, it could equally be said that the regulation was in connection with the sale of products, not their importation. There is arguably no basis for finding that the provision in Cassis de Dijon - a ban on the sale of insufficiently strong alcoholic beverages - was connected to imports while finding no similar connection in the ban in Blesgen on sales of strong alcoholic beverages in hotels. ${ }^{46}$ Consequently, Oebel and Blesgen are now considered to have been exceptions ${ }^{47}$ to the current of Court of Justice jurisprudence according to which, as a general rule, even the indistinct application of non-protective marketing restrictions is a hindrance to trade. ${ }^{48}$

44. Case 155/80, Proceedings against Oebel, [1981] E.C.R. 1993 [hereinafter Oebel]; Case 75/81, Blesgen v. Belgium, [1982] E.C.R. 1211 [hereinafter Blesgen].

45. Ibid. at 1211 .

46. In fact, White and Mortelmans might suggest that the former rule is a product standard, while the latter rule is mere regulation of «market circumstances». See infra, text accompanying note 80 et seq.

47. However, Oebel and Blesgen were recently followed by the Court of Justice in Case C23/89, Quietlynn Ltd. v. Southend B.C., [1990] E.C.R. I-3059.

48. For example, Case 788/79, Gilli, [1980] E.C.R. 2071; Case 178/84, Commission v. Germany, [1988] 1 C.M.L.R. 780 [law regulates use of designation «beer»]; Case 193/80, Commission v. Italy, [1981] E.C.R. 3019 [law prohibits sale of acetic acid not made from wine]; Case 16/83, Prantl, [1984] E.C.R. 1299 [German law prohibits sale of wines in bottles of a particular shape]; Case 59/82, Schutzverband gegen Unwesen in der Wirtschaft v. Weinvertriebs, [1983] E.C.R. 1217 [German law requires all imported wine to conform to production requirements of country of production]. But see Case 216/84, Commission v. France, [1988] E.C.R. 793 [non-protectionist ban on substitute milk powder violates Article 30]. 
Cinéthèque v. Fédération nationale des cinémas français ${ }^{49}$ played an important role in confirming the general rule, since unlike the German rule on fruit liqueurs in Cassis de Dijon, the impugned measure in Cinéthèque was not protectionist in purpose and had the same impact on foreign and national producers. The legislation prohibited the sale of movies in videocassette form for a short period after the release of the film in cinemas. The Court of Justice accepted that the purpose and effect of the legislation was to protect the cinematographic industry in general, and not the French industry in particular. ${ }^{50}$ It concluded that in principle, the legislation was inconsistent with the free movement of goods because of disparities among the Member States' regulation in this field, but that it was acceptable as a means of protecting the cinematographic form. Thus, in Cinéthèque, the Court of Justice remained true to the statements in Cassis de Dijon declaring that regulation which is not harmonized across the Community is prima facie inconsistent with the principle of the free movement of goods even if it is non-discriminatory. ${ }^{51}$

The second important development in Cinéthèque relates to the derogation created in Cassis de Dijon. According to the prevailing view, the Court of Justice did nothing more than make the protection of cinematography an exigence impérative. ${ }^{52}$ However, the Court of Justice did not refer even once in its judgment to the concept of exigences impératives. It merely held that the objective was «justified with regard to Community law» and gave no further explanation. Thus, we do not truly know whether the ECJ considered the promotion of cinematography to be of such an «imperative» nature as to warrant overriding a fundamental principle of the Common Market, whether the measure was justified under Article 36, or whether the Court of Justice simply conjured up another, more lenient exception to Article 30.

Despite the uncertainty surrounding the scope of the derogation following the cryptic judgment in Cinéthèque, the Court of Justice has consistently indicated that in principle, Article 30 extends to national measures which are not discriminatory and which do not have a disproportionate impact on imports. In the language of the Court of Justice, such measures are nevertheless «capable of hindering intra-Community trade», in the absence of harmonization across the Community.

49. Cases 60 and 61/84, [1985] E.C.R. 2605 [hereinafter Cinéthèque].

50. It is not clear why it was not argued, however, that the legislation was protective in effect because it benefited French cinema operators at the expense of Community (including French) videocassette distributors.

51. K. Mortelmans, «Article 30 of the EEC Treaty and Legislation Relating to Market Circumstances» (1991) 28 C.M.L.Rev. 115 at 120.

52. Steiner, Textbook, supra, note 3 at 75 ; White, supra, note 25 at 244; Oliver, supra, note 15 at 88 . 


\section{B. Indistinctly Applicable Measures and the Canadian Common Market}

It was observed at the beginning of this paper that in Canada, provincial measures which are not discriminatory and which do not have an excessive effect on interprovincial trade flows are within the province's constitutional vires. Thus, in Canada, the balance chosen by the courts between the protection of the common market and the integrity of the legislative jurisdiction of the provinces reflects a somewhat narrower vision of the free movement of goods than that adopted by the ECJ. At this point, it is useful to review briefly the Canadian jurisprudence in order to explain how the difference in approach arose.

Canada's equivalent of Article 30 EEC is the so-called «common market clause» in section 121 of the Constitution Act, $1867 .{ }^{53}$ It provides :

«All Articles of the Growth, Produce, or Manufacture of any one of the Provinces shall ... be admitted free into each of the other Provinces.»

It might be thought that section 121 is worded even more broadly than Article 30 : a guarantee that goods shall be «admitted free» is arguably more liberal than a prohibition against «measures having an effect equivalent to quantitative restrictions on imports». Indeed, the wording of section 121 is similar to the «duty to admit» formulated by the EC Commission in response to Cassis de Dijon. ${ }^{54}$ However, section 121 has been interpreted much less liberally than Article 30 EEC. In fact, it turns out that Canada's «common market clause» is little more than a duty on provinces not to impose tariffs on products from other provinces. $^{55}$

For this reason, section 121 is not useful against non-tariff trade barriers. Consequently, restrictions on provincial power to enact regulation affecting trade within the federation have been elaborated principally by reference to the division of powers in sections 91 and 92 . The basic rule is that provinces may not enact legislation whose «pith and substance» is the regulation of interprovincial trade :

53. (U.K.), 30 \& 31 Vic., c. 3.

54. See supra, note 41 and accompanying text.

55. Murphy v. C.P.R., [1958] S.C.R. 626 at 634; Gold Seal Ltd. v. Dominion Express Co. (1921), 62 S.C.R. 424. See also M.J. Trebilcock, «Federalism and the Canadian Economic Union» in H. Bakvis and W. Chandler, eds., Federalism and the Role of the State (Toronto : U.T. Press, 1987) at 217. 
«It is not the possibility that these orders might «affect» the appellant's interprovincial trade which should determine their validity, but, rather, whether they were made «in relation to» the regulation of [interprovincial] trade and commerce.... The fact of such impact may be relevant in determining their true aim and purpose, but it is not conclusive. ${ }^{56}{ }$

Thus, provincial legislation is valid as long as its «true purpose» is not to regulate interprovincial trade.

Because the main restriction on provincial non-tariff barriers in Canada is contained in the limits to the provinces' legislative jurisdiction under section 92-13 rather than the «common market clause», there are two major weaknesses in Canada's common market in comparison to that of the EC. First, the limits in s. 92-13 bind only the provincial legislatures. Second, s. 92-13 grants the provinces a wide leeway to use or spend provincial public property, even if the purpose of the spending would exceed the provincial regulatory competence. ${ }^{57}$ In contrast, Article 30 EEC applies to the executive and legislative branches of government of the Member States and to all institutions of the Community itself, and makes no explicit distinction between regulatory and non-regulatory «measures». ${ }^{8}$ Thus in Canada, discriminatory government procurement policies, such as those at issue in the recent Ontario-Québec and Québec-New Brunswick trade conflicts, ${ }^{59}$ and federally-sanctioned interprovincial trade barriers, such as those authorized by the Farm Products Marketing Agencies Act, S.C. $1970-71-72$, c. 65 , continue to impair the internal market. ${ }^{60}$

Assuming that section 92-13 applies, the determination of whether it has been exceeded by a particular measure is approached very differently from the manner articulated by the ECJ in Dassonville and Cinéthèque. Whereas the European Court of Justice considers the purpose of the measure to be irrelevant

56. Carnation, supra, note 1 at 252-53.

57. For example, provinces have acquired airlines and given international aid : see P. Hogg, Constitutional Law of Canada, 2d ed. (Toronto : Carswell, 1992) at 6-20 to 6-21 and 28-2 to $28-5$.

58. Oliver, supra, note 15 , ch. 4 . See for example the case involving the «Buy Irish» campaign, Commission v. Ireland, supra, note 25, and accompanying text.

59. See A. Pépin, «Barrières interprovinciales : [Le premier ministre ontarien] Rae menace le Québec de mesures punitives» La Presse, 2 September 1993, B5; D. Lessard, «Québec et Queen's Park concluent un armistice» La Presse, 24 December 1993, A1; K. Cox and B. McKenna, «N.B. Bans Québec Workers, Bidders» The Globe and Mail, 22 April 1993, A1. See also M.J. Trebilcock, J. Whalley et al., «Provincially Induced Barriers to Trade in Canada : A Survey» in M.J. Trebilcock, J.R.S. Prichard et al., Federalism and the Canadian Economic Union (Toronto : U.T. Press, 1983) at 243-47 [hereinafter Trebilcock, Whalley et al.].

60. See Trebilcock, Whalley et al., ibid. at 254-57. 
(1993) 24 R.D.U.S.

Free Movement of Goods in the European Community :

A critique of the jurisprudence

on Article 30 of the Treaty of Rome

in determining whether it prima facie violates Article 30 EEC, a law's purpose will be determinative of its constitutionality under s. 92-13. A discriminatory provincial law will probably be beyond the province's power under s. 92-13 because its aim is to regulate interprovincial trade, while a law with a legitimate objective relating to the regulation of local commerce will usually be intra vires. It is true that Carnation suggests that an intention to regulate interprovincial trade might be imputed to the province on the basis of the effects of the measure. ${ }^{61}$ However, assuming that any extraprovincial effects are reasonably incidental to the aim of the legislation, and that there is no other evidence of an unconstitutional purpose, the law will be a valid exercise of provincial power. ${ }^{62}$ In particular, indistinctly applicable measures whose purpose and effect are not discriminatory will not be considered to interfere with Canadian interprovincial trade, even if they are capable of having an impact on the flow of goods across boundaries. In contrast, as previously pointed out, such measures would violate Article $30 \mathrm{EEC}$, following Dassonville and Cinéthèque, unless they could be justified with reference to an imperative national interest or under Article 36.

\section{Article 30 and Harmonization}

The main rationale for applying Article 30 to non-discriminatory indistinctly applicable measures is that in the absence of harmonization they may constitute barriers to trade. Article 30, it is often argued, must be construed so as to further the elimination of these barriers :

«Prise dans son acceptation la plus large, la notion de "libre circulation des marchandises" doit ... être interprétée en fonction de l'objectif à atteindre, à savoir la réalisation de conditions communes et uniformes permettant aux produits de circuler entre les pays de la Communauté comme à l'intérieur d'un marché national. ${ }^{63}{ }^{3}$

Although this assertion is not without merit, it does not follow that Article 30 is the proper tool to remove disparities among national legislative régimes.

61. Supra, note 1 at 252-53. The principle would appear to have been applied in Manitoba (A.G.) v. Manitoba Egg and Poultry Association, [1971] S.C.R. 689 as well as in Manitoba (A.G.) v. Burns Foods Ltd., [1975] 1 S.C.R. 494 [hereinafter Burns Foods].

62. In Burns Foods, ibid., esp. at 505, the Court ruled the provincial plan ultra vires because its extraprovincial reach could not be characterized as reasonably ancillary to a legitimate provincial objective.

63. Mattera, supra, note 16 at 501. 
To some extent, the purpose of the European Common Market is to achieve integration for its own sake. ${ }^{64}$ However, it bears remembering that the usual justification for a common market is that it generally results in economic gains for the nations involved. ${ }^{65}$

The gains from the removal of trade barriers can be sorted into a number of categories. First, the removal of trade barriers permits production of a particular good to gravitate to areas within the bloc where there is a comparative advantage in its production. ${ }^{66}$ This permits producers to realize economies of scale by serving a larger market. Equally importantly, quite apart from economies of scale, shifting production of a good to an area with a comparative advantage gives rise to a more efficient production pattern across the common market. ${ }^{67}$ Hereinafter, these savings will be referred to as arising from the efficient geographic allocation of production.

Less often mentioned is what may be termed the gain from the elimination of a «local distortion». By this expression I mean that a national trade barrier is also distortive of local consumption decisions, because it is theoretically equivalent to a production subsidy plus a consumption tax. ${ }^{68}$ Thus, the elimination of a tariff or product standard removes a «wedge» from between relative prices and relative costs in the domestic market, so that the domestic equilibrium is closer to its efficient point, assuming that the unregulated equilibrium is efficient in the local market. The shift in the domestic equilibrium has consequences for trade flows since any hindrance to overall consumption restricts in particular the consumption of imports.

The costs of trade barriers are incurred regardless of whether the barriers result from protectionism or simply disparities among regulation in the Member

64. One of the ultimate objectives of the treaties of the European Communities, which were negotiated in the decade following the Second World War, was to increase the interdependence of the Member States so as to ensure a durable peace in Europe : see H.J. Küsters, Fondements de la Communauté économique européenne (Office des publications officielles des Communautés européennes, Brussels : Labor, 1990) at 2.

65. M. Trebilcock mentions a number of exceptions to the generalization of economic gains from the removal of trade barriers in «Federalism and the Canadian Economic Union»: supra, note 55 at 218.

66. See M. Chacholiades, International Economics (New York : McGraw-Hill, 1990) at ch. 2.

67. For example, independently of any economies of scale, efficiency is enhanced within the European Common Market if Denmark produces animal furs and Portugal cultivates citrus fruit, rather than both countries attempting to produce both goods. Production does not necessarily shift to the producer with the lowest absolute costs, because to say that a country has a comparative advantage in the production of a particular commodity is simply to say that the pre-trade opportunity cost of the commodity is lower. See further Chacholiades, supra, note 66 at $18,23-24$.

68. See Chacholiades, supra, note 66 at 157. 
(1993) 24 R.D.U.S.

Free Movement of Goods in the European Community :

A critique of the jurisprudence

States. If national standards differ, even if not for protectionist reasons, and even if no domestic industry obtains an advantage, the ability of a producer to serve the entire Community market is impaired, as is the ability of a purchaser to obtain its goods where they may be produced at the least relative cost. Similarly, the distortive effects on trade flows which result from the «wedge» between prices and costs in the national market are also independent of the protectionist character of the regulation. It is for this reason that the Court of Justice in Cassis de Dijon and Cinéthèque considered a protectionist motive or protective effect to be irrelevant where there was an absence of harmonization among Member States.

However, once a disparity has been identified as a trade barrier, the question remains as to what obligation Article 30 imposes on the Member States. In a situation where a national standard has been adopted with protectionist intent, or even where it simply has the effect of protecting a national market, there is a case for singling it out as responsible for the trade barrier. In contrast, in the absence of protectionist motive or protective effect, the trade barrier cannot be attributed to any of the standards individually.

It may appear at first blush that the Member States adhering to stricter standards can be blamed for the trade barrier. This is the position implicit in the principle of mutual recognition articulated in Cassis de Dijon and Cinéthèque. It is submitted that this preference for the lowest standard is unjustified. Suppose, for example, that starting from a position of equal regulation, one nation passes a law to relax its standard. As a result, trade between that State and the others will be restricted, because a rational producer may be induced to produce a special run for the low-standard market, depending on the offsetting diseconomies of small scale. According to Cassis de Dijon and Cinéthèque, all the other nations would be required to match the new, lower standard, or to justify their passivity by reference to an imperative national interest. As Marenco points out,

«Le traitén'a pas pour but d'interdire les réglementations en tant que telles, afin de parvenir à l'uniformité des réglementations par leur simple suppression. ${ }^{69}{ }_{\gg}$

Yet, the interpretation forwarded in Cassis de Dijon and Cinéthèque sets the stage for a mandatory «race to the bottom». ${ }^{70}$

69. G. Marenco, «Pour une interprétation traditionnelle de la notion de mesure d'effet équivalant à une restriction quantitative» (1984) 20 C.D.E. 291 at 318

70. To be fair, States would still be able to apply whatever standard they choose to products which are produced within the State, as long as they do not require compliance by imported products. 
On the other hand, it might be argued that the more rigorous product standard can be singled out because of the greater magnitude of the trade effects of its «local distortion». As I have explained, above, a national standard is equivalent to a consumption tax and a production subsidy : therefore, the more strict the regulation, the more «distortive» of overall consumption is the subsidytax combination. Recall that this distortion affects imports because purchases of imported products are part of overall consumption.

I would suggest, however, that this argument is not tenable. The local distortion accompanying a regulation is of a different nature from any geographic misallocation of production. While the latter is a special feature of protectionism and legislative disparities, the former is the inevitable consequence of all kinds of government intervention in the economy. Moreover, since this part of the trade effect flows exclusively from the fact of domestic economic regulation, its magnitude is independent of the standards adopted by the other Member States. In other words, the effect of the local distortion on sales of imports in a Member State would be the same regardless of whether other Member States had no standard, the same standard or a higher standard. It is therefore illogical to assign responsibility for the absence of harmonization on the basis of this trade effect.

In summary, therefore, although a lack of harmonization of regulations within the Common Market causes a geographic misallocation of production, this misallocation cannot be attributed to any of the Member States individually. In particular, it cannot be imputed to those Member States having stricter regulations. ${ }^{71}$

Some Euro-scholars scarcely conceal their bias against regulation when they argue that harmonization can be achieved by means of Article 30 . For example, in defence of his broad view of the free movement of goods, Mattera notes with concern

«[c]e phénomène inquiétant et grandissant de l'intervention des États dans la vie économique de leur pays par des mesures touchant aux domaines les plus disparates... ${ }^{72} \gg$

Yet, unless regulation is per se antithetical to the Common Market, the «distortive» effects inherent to regulation are not an appropriate basis for considering a non-discriminatory, non-protective national measure to be responsible for a trade barrier that arises from legislative disparities.

71. Marenco, supra, note 69 at 320.

72. Mattera, supra, note 16 at 518-19. 
Article 30 is too crude an instrument for achieving the goal of harmonization because it provides no rule for choosing among the competing standards. It is significant that pursuant to Article 100A of the Treaty, the EC Commission is leading efforts to achieve agreement among the Member States on harmonized legislation. The Commission's work would be futile if harmonization could be achieved through the direct application of Article 30 in order to invalidate national legislation. This cannot have been the purpose of Article 30.

\section{The Requirement of Disadvantage}

In an article written before the Court of Justice's decision in Cinéthèque, Marenco argued that discrimination or disadvantage is necessary to trigger Article 30. In his view, the object of Article 30 is not fundamentally to achieve harmonization, however desirable that objective may be in the context of the Common Market, but rather

«... d'établir la communication entre les économies et mettre en concurrence, à parité de conditions, les facteurs de production nationaux et les facteurs correspondants des autres États membres. ${ }^{73}{ }_{\text {» }}$

Communication and competition between national economies and factors of production would favour an efficient geographic allocation of resources. They would be achieved, as far as possible, by the elimination of national measures which have discriminatory intent or which place imports at a disadvantage relative to national products. Marenco's theory has been widely rejected by other academic writers, ${ }^{74}$ and the Court of Justice clearly opted for harmonization in Cinéthèque. It will be argued, however, that the detractors of the «theory of disadvantage» do not propose any convincing alternative.

Marenco's concept of discrimination is very broad. It is, of course, beyond doubt that the different treatment of situations which are the same is discriminatory. Measures which effect «formal discrimination» of this kind, for example the requirement in Dassonville of a certificate of origin for imported liquor, automatically fall foul of Article $30 .{ }^{75}$ However, indistinctly applicable measures are also capable of discriminating against imported products : an apparently neutral provision may have a protectionist object or may be more

73. Supra, note 69 at 316.

74. See White, supra, note 25 at 244; Oliver, supra, note 15 at 91; Gormley, Prohibiting Restrictions on Trade within the EEC (The Hague, 1985) at 264-65. See also for example Steiner, «Drawing the Line», supra, note 13 at 770; Mattera, supra, note 16, both of whom agree that disadvantagement and protectionism are both irrelevant.

75. Marenco, supra, note 69 at 305, 312; Oliver, supra, note 15 at 90. 
onerous in effect for imported products. ${ }^{76}$ The minimum alcoholic content regulation in Cassis de Dijon is an example : since the alcoholic content of fruit liqueurs traditionally varied from region to region, to impose a minimum standard placed imports at a disadvantage. ${ }^{77}$ The adverse impact imposed on imported products by this sort of indistinctly applicable measure is labelled «discrimination matérielle». It is argued that only if the provision is formally discriminatory or has a discriminatory adverse impact is there a trade barrier that can be attributed to the measure.

Marenco's interpretation of Article 30 has the advantage of being consistent with the Court of Justice's interpretation of the prohibition on export restrictions in Article 34, which is phrased virtually identically to Article $30{ }^{78}$ In Groenveld, a case on Article 34 decided shortly after Cassis de Dijon, the ECJ held that indistinctly applicable production regulations are not measures having an effect equivalent to export restrictions unless their intent or effect is discriminatory. ${ }^{79}$

Many of the writers who disavow Marenco's theory nevertheless agree that the scope of Article 30 should be narrower than that adopted by the Court of Justice in Cassis de Dijon and Cinéthèque, and have proposed their own criteria for limiting the scope of Article 30 without resorting to the derogation for exigences impératives. White, for example, would draw a line between regulation of the characteristics of products and regulation of the circumstances in which they are marketed. According to his theory, only regulation of the first kind, regarding the size, shape, content, packaging and labelling of a product, for example, has the potential to hinder the progress of the Common Market. ${ }^{80}$ Regulation of the second type, relating to the time, place and manner of sale of a product, for example, is considered innocuous.

But while White claims that Marenco's theory is «untenable», ${ }^{81}$ it is submitted that in fact White's own theory is very similar to it. Indeed, Marenco

76. Although it is far beyond the scope of this paper to compare Marenco's definition of discrimination to the treatment of the concept in Canadian human rights law, the extension of the concept of discrimination to include situations of formal equality but material disadvantage is evident in cases under the Charter and the human rights codes. See Andrews v. Law Society of B.C., [1989] 1 S.C.R. 143.

77. This point was made in the judgment in Cassis de Dijon, supra, note 32 at para. 14. See also Marenco, supra, note 69 at 306.

78. Article 34 reads : «Quantitative restrictions on exports, and all measures having equivalent effect, shall be prohibited between Member States.» For an attempt to explain the discrepancy in the ECJ's interpretation of two essentially identically-worded provisions, see Steiner, Textbook, supra, note 3 at 80; Oliver, supra, note 15 at 90, 98-103.

79. Case 15/79, P.B. Groenveld B.V. v. Produktschap voor Vee en Vlees, [1979] E.C.R. 3409.

80. White, supra, note 25 at 259.

81. Ibid. at 244 . 
expressly refers to measures requiring a «manipulation of products» as being contrary to Article 30 if they are excessive or unnecessary. ${ }^{82}$

It is important to keep in mind why measures of this kind may be objectionable. Rules relating to the characteristics of products often impose additional costs on importers, for example, if a special production run is required for a particular national market. Indeed, if importers are compelled to incur extra expenses to comply with standards which are already in use in domestic production, the measure can be attacked on grounds of discrimination matérielle. Note, however, that it is not the disparity among the rules in force in various States, but rather the adjustment cost borne by importers to comply with a particular rule, which gives rise to discrimination materielle. If the disparity does not result in importers incurring compliance costs which domestic producers do not have to expend, there is no discriminatory impact and hence, no violation of Article 30.

White founds his argument on an analysis of the case law of the Court of Justice. In most cases where the ECJ has found a violation of Article 30, the national regulation related to the characteristics of the product. However, even acknowledging that product characteristics regulation is more likely to obstruct the Common Market than is market circumstances regulation, it is submitted that the real reason for this correlation is not that characteristics legislation is inherently incompatible with the Common Market, but that characteristics legislation more often imposes a special burden on imports.

In some situations, this special burden on imports can be identified even if the regulation is characterized as regulation of circumstances. For example, the Belgian appellant in G.B.-Inno-B.M. v.A.T.A.B. ${ }^{83}$ complained that it would be forced to redesign its marketing strategy for the Luxembourg market in order to comply with local prohibitions on the use of certain kinds of advertising. The Court of Justice was persuaded by a similar argument in Oosthoek's case. ${ }^{84}$

It may be for this reason that Mortelmans proposed to include, in addition to characteristics regulation, measures regulating market circumstances which were not territorially confined. Thus, a restriction on door-to-door selling would prima facie violate Article 30 , but a rule on store closing hours would

82. Marenco, supra, note 69 at 312. Marenco considers these measures to violate Article 30 but says they are not «matériellement discriminatoires». In my view, however, it is much simpler, not to mention more consistent with the rest of Marenco's approach, to analyze them within the framework of discrimination matérielle.

83. Case 13/77, [1977] E.C.R. 2115.

84. Proceedingsagainst Oosthoek's Uitgeversmaatschappij B.V., [1983] 3 C.M.L.R. 428 at 445 , para. 15. 
not. ${ }^{85}$ Unfortunately, Mortelmans' explanation for adding territoriallyunconfined market circumstances rules to the scope of Article 30 is cursory and unclear: perhaps if the rules are confined as to location, then in some sense they are closer to being a regulation of the use of a fixed place, with the good «only a secondary consideration $» .{ }^{86}$

Ultimately, however, it is submitted that the key to finding a threat to the Common Market is in identifying a special burden on imports. The labels «characteristics» and «circumstances» proposed by White and Mortelmans are conclusory. For example, in cases like Blesgen ${ }^{87}$ (prohibition on sale of strong alcoholic beverages in hotels), how do we decide whether a measure relates to the characteristics of the product or merely the circumstances of its sale? Important questions, namely the validity of the legislation, should not depend on a distinction which is indeterminate and which may be subject to manipulation by legislative drafters.

In Torfaen, Advocate General Van Gerven expressed a preference for a test based on whether the effect of the measure was to contribute to the partitioning of the Common Market into separate national markets. ${ }^{88} \mathrm{He}$ had drawn this test from the Court of Justice's interpretation of the prohibition against anti-competitive collusive activity in Article $85 .{ }^{89}$ In its jurisprudence on Article 85, the ECJ had interpreted the phrase «which may affect trade between Member States» so as to require that an agreement or concerted practice have an appreciable partitioning effect on intra-Community trade before it would be subject to the Article. As Van Gerven noted, both Article 30 and Article 85 are about the hindering of trade within the Community, and pursue the same objective, namely to protect the Common Market. ${ }^{90}$

There are, however, a number of problems with Van Gerven's approach. In the first place, although Articles 30 and 85 both have as their «fundamental purpose» the protection of the Common Market, it is not clear that they are protecting it from the same threat. Moreover, as Van Gerven himself noted, one of the purposes of the threshold in Article 85 is «to delimit the field of application» of Community competition law from national competition law. ${ }^{91}$

\footnotetext{
85. Mortelmans, supra, note 51 at 130.

86. Ibid.

87. Supra, note 44

88. Torfaen, supra, note 2 at 148-49.

89. Article 85 prohibits «all agreements ... and concerted practices which may affect trade between Member States and which have as their objective or effect the prevention, restriction or distortion of competition within the common market ...»

90. VerLoren van Themaat also observes a convergence in ECJ jurisprudence between the rules on the free movement of goods and the rules on competition. See supra, note 35 at 134.

91. Torfaen, supra, note 2 at 148.
} 
(1993) 24 R.D.U.S.

Free Movement of Goods in the European Community :

A critique of the jurisprudence

on Article 30 of the Treaty of Rome

In this context, it makes sense to require potentially restrictive agreements to have some effect on trade at the Community level before subjecting them to the Community regime.

On the other hand, it could be argued that it makes as much sense to require potentially restrictive national legislation to have a minimum of effect on trade at the Community level before finding it to be a threat to the Common Market. Indeed, both Mortelmans and Steiner considered Van Gerven's test to be a disguised de minimis threshold..$^{92}$ If it is a threshold rule, it has to be disguised because the Court of Justice expressly rejected the idea of a de minimis rule for Article 30 in the van de Haar case. ${ }^{93}$

In many cases, if a national market is «screened off», it will be possible to say that imported products have been excluded from the market in a manner which places them at a disadvantage relative to domestic substitutes and thus, to find discriminatory impact. This was the case in Cassis de Dijon. On the other hand, cases such as Cinéthèque and Commission v. France ${ }^{94}$ are examples of situations where measures had the effect of closing off the national market without any formal or adverse-impact discrimination between national and imported products. It is tempting to conclude in these cases that any measure which tends towards the partitioning of the Common Market cannot possibly be compatible with the principle of the free movement of goods and the maintenance of the Common Market.

Ultimately, however, Van Gerven's theory is vulnerable to the same criticisms as the theory adopted by the Court of Justice. The fact is that whenever regulation in an area is not harmonized, the integration of the Common Market is imperfect, because partitioning occurs in some degree. As I have already argued, this partitioning cannot be attributed to any particular Member State's regulation, and it cannot be rectified through a process of harmonization which uses Article 30 to compel all States to adhere to the lowest common denominator.

92. Article 85 illustrates how a de minimis rule would operate. It was mentioned in the text accompanying note 89 , supra, that Article 85 prohibits collusive activity only if it has an appreciable impact on intra-Community trade. If its impact is insignificant, then any theoretical violation of Article 85 is de minimis. According to Mortelmans, this is the kind of test Van Gerven is implicitly proposing for Article 30 : see Mortelmans, supra, note 51 at 128; Steiner, «Drawing the Line», supra, note 13 at 772.

93. Cases 177-78/82, Criminal Proceedings against Van de Haar, [1984] E.C.R. 1797.

94. Supra, note 48 [powdered milk]. 


\section{Sunday Trading}

Sunday observance legislation might have been challenged under the freedom of religion clause at Article 9(1) of the European Convention on Human Rights. Article 9(1) might support an argument similar to that accepted by the Supreme Court of Canada in Edwards Books, ${ }^{95}$ namely that the requirement to stop work on the Christian pause day imposes a special burden on those individuals and groups whose religion requires them to observe a different day of the week. But who can blame the business-owners in Torfaen, Conforama, Marchandise, and Stoke-on-Trent ${ }^{96}$ for challenging their national Sunday legislation instead under the Treaty of Rome? Unlike the European Convention of Human Rights, the Treaty of Rome is directly effective and it prevails over incompatible domestic legislation in all Member States. ${ }^{97}$

\section{A. The Sunday Trading Cases as a Development of the Cinéthèque Line}

In the first of these cases to be decided, Torfaen Borough Council v. B $\& Q p l c$, the Borough Council was attempting to enforce the Shops Act 1950, ${ }^{98}$ a British statute making it an offence for a store to open on Sundays in England or Wales, except as provided for in a series of exceptions. One storeowner raised as a defence that the Shops Act violated Article 30 and should not be applied. Pursuant to Article 177 of the EEC Treaty, the local Magistrates' Court referred preliminary questions relating to the shop's «Euro-defence» to the Court of Justice.

The Court of Justice ruled as follows :

«Article 30 of the Treaty must be interpreted as meaning that the prohibition which it lays down does not apply to national rules prohibiting retailers from opening their premises on Sunday where the restrictive effects on Community trade which may result therefrom do not exceed the effects intrinsic to rules of that kind. ${ }^{99}{ }$ 》

Note that since the Court of Justice does not have jurisdiction under Article 177 to rule on the compatibility of a particular piece of national legislation with Community law, its ruling is phrased in general terms. The ultimate «validity»

95. Edwards Books and Art v. R., supra, note 20.

96. The four Sunday Trading cases are cited at note 2, supra.

97. See N. Marsh, «What Rights are Fundamental - The United Kingdom's Dilemma» in de Mestral et al., eds., supra, note 14 at 515 et seq.

98. (U.K.) 14-15 Geo. VI, c. 28.

99. Torfaen, supra, note 2 at 157. 
(1993) 24 R.D.U.S.

Free Movement of Goods in the European Community :

A critique of the jurisprudence

on Article 30 of the Treaty of Rome

of the British law would have to be determined by the national court, having regard to the proportionality of the «restrictive effects» of the law on trade within the Community. ${ }^{100}$

The reasons offered by the Court of Justice for ruling that the prohibition in Article 30 «does not apply» reveal that the ECJ applied Cinéthèque. In its judgment, the Court of Justice began by recalling that in Cinéthèque, the impugned measure

«... was not compatible with the principle of the free movement of goods provided for in the Treaty unless any obstacle to Community trade thereby created did not exceed what was necessary in order to ensure the attainment of the objective in view and unless that objective was justified with regard to Community law.

In those circumstances it is therefore necessary in a case such as this to consider first of all whether rules such as those at issue pursue an aim which is justified with regard to Community law. ${ }^{101}{ }_{\gg}$

It would appear from these observations that the ECJ considered Sunday legislation to be an obstacle to the free movement of goods. Thus it fell to be considered whether the measures could be justified under the principle of derogation articulated in Cinéthèque.

The above excerpt from Torfaen is repeated in two subsequent Sunday Trading judgments, Conforama and Marchandise. In these two cases, the Court of Justice dealt with challenges by retailers to the Labour Codes of France and Belgium, respectively, which restricted the employment of staff on Sundays.

In all three cases, the national court had asked the Court of Justice to assume that some portion of the goods that the shops would have sold on Sunday were imported goods. In finding that the effect on the shops' sales of imports was as a matter of Community law a «restrictive effect on intra-Community trade», the Court of Justice extended the «duty not to regulate» beyond the context contemplated in Cassis de Dijon and Cinéthèque.

Unlike the situation in Cassis de Dijon and Cinéthèque, disparities among national laws on retail hours had absolutely nothing to do with any

100. Although it has previously asserted that the validity of national legislation is a matter for the national courts, the Court of Justice has since ruled that as a general rule, Sunday observance legislation will not violate Article 30. See the discussion of the decision in Stoke-on-Trent, infra, at note 114 and the accompanying text.

101. Torfaen, supra, note 2 at 156. 
reduction in the sales of imported products in the U.K., France or Belgium. If anything, differences in national policies in this regard might increase crossborder trade in goods (as Ontario retailers' recent experience illustrates). This point, which was raised by the Commission before the ECJ in Torfaen, was rejected by the Advocate General and ignored in the judgment of the Court of Justice. ${ }^{102}$ Advocate General Van Gerven's response was that as long as the rule prevents sales of imports which might otherwise occur in the absence of the rule, it is a hindrance to intra-Community trade. ${ }^{103}$

Indeed, the ECJ now asserts that an obstacle to trade may arise in the absence of any protectionist intent, disadvantagement, or disparity among national laws. I would suggest that in fact, if none of these features are present, there is no barrier to trade : since there is no protectionism or legislative disparity, the geographic allocation of production is not distorted. In consequence, the only trade effect of Sunday legislation is that which is attributable to the «local distortion», namely the import component of the disruption in consumption which arises because of the theoretical equivalency of the regulation to a consumption tax. But as I argued above, ${ }^{104}$ this effect is common to all regulation, ${ }^{105}$ indeed to all interventions by the State in the economy. If even this impact on the flow of goods across boundaries is of a nature to trigger Article 30, then almost any conceivable regulatory measure of general application is also caught. Moreover, elementary macroeconomic theory tells us that any exercise of fiscal or monetary policy which affects aggregate demand will have an impact on the level of imports. ${ }^{106}$ Are all of these measures to be considered «measures having equivalent effect» unless they can be justified as exigences impératives or under Article 36 ?

The answer is no. To find a violation of a fundamental principle of the Common Market in those circumstances would be inconsistent with the idea that the Member States have retained jurisdiction to regulate any aspect of their domestic economy. Aside from being antithetical to the principle of subsidiarity, ${ }^{107}$ such an interpretation would be unreasonable because the

102. Torfaen, supra, note 2 at $138 \mathrm{~h}$

103. Torfaen, supra, note 2 at $142 \mathrm{a}$.

104. See discussion, supra, note 71 and accompanying text.

105. A similar argument was alluded to but not seriously considered by the Advocate General in Torfaen, supra, note 2 at $143 \mathrm{~d}$.

106. See R. Lipsey, D. Purvis, P. Steiner, Economics, 6th ed. (New York : Harper \& Row, 1988) at 593.

107. Though its precise content is uncertain, one accepted formulation of the subsidiarity principle of Community law states that regulation is to be left to the Member States unless for reasons of effectiveness or convenience it is best handled at the Community level. See N. Emiliou, «Subsidiarity : An Effective Barrier against 'the Enterprises of Ambition'?» (1992) 17 E.L.Rev. 383 at 391. 
(1993) 24 R.D.U.S.

Free Movement of Goods in the European Community :

A critique of the jurisprudence

on Article 30 of the Treaty of Rome

Member States could not have intended in ratifying Article 30 to divest themselves of their ability to develop and apply economic policies on their own territories. ${ }^{108}$

There is no justification for the Court of Justice's contention in Torfaen, Conforama and Marchandise that a regulation can still be restrictive of Community trade if it is applied indistinctly, is not discriminatory, and is uniform throughout the Community. Yet, the overall consistency of these judgments with the ECJ's reasoning in Cinéthèque and Cassis de Dijon is striking. In the two latter cases, although the evil addressed was the absence of harmonization, the assumption on which the cases proceeded was that all regulation has the potential to be distortive of trade within the Common Market. The resulting preference for the lowest common denominator is not explicable by a theory of optimal geographic allocation. I have argued that only an independent aversion to regulation can account for the approach to Article 30 asserted in the Cassis de Dijon-Cinéthèque line and in the Sunday Trading cases.

Article 30 was not meant to be interpreted in such a way as to require all regulation to be justified as an exception to the principle of the free movement of goods. As White has argued,

«If Article 30 is allowed to become a quasi-constitutional instrument which complainants and courts can use to question the justification and «proportionality» of virtually all State measures regulating society, then the Court of Justice will inevitably be led ... either to greater laxity in recognising measures as justified or to call into question the direct applicability of Article $30 .{ }^{109}{ }_{\text {» }}$

The judgments rendered by the Court of Justice in Torfaen, Conforama and Marchandise show that White was correct.

In fact, when Cassis de Dijon first introduced the concept of exigences impératives, the Commission's statement on its scope reflected the general consensus about the standard of importance the overriding objective had to meet:

108. The same argument was invoked in the context of Article 85 (anti-competitive practices) by the Advocate General in Case 229/83, Leclerc v. Au Blé Vert, [1985] E.C.R. 1 at 22.

109. Supra, note 25 at 239. 
«Ce but doit être de nature à primer les exigences de la libre circulation des marchandises qui constitue l'une des règles fondamentales de la Communauté. ${ }^{110}{ }$

First weakened by the ambiguous reference in Cinéthèque to the objective of protecting cinematography as being «justified in Community law», the concept of exigences imperatives is now unrecognizable. ${ }^{11}$ In Torfaen, the Court of Justice considered that the objective of the legislation was to «ensure that working and non-working hours are so arranged as to accord with national or regional socio-cultural characteristics», and that this objective was «a matter for the member states.» ${ }^{112}$ Similar objectives in Conforama and Marchandise were also held to be «a matter for the member states.» ${ }^{113}$

A fourth Sunday Trading case, decided near the end of 1992, confirmed the trend. Stoke-on-Trent involved a second reference relating to the Shops Act 1950. This time, the Court of Justice did not even repeat the formulation inspired by Cinéthèque, according to which Sunday closing legislation was prima facie an obstacle to trade. Instead, it simply noted the legitimacy of the objective and the proportionality of the measure :

«[L]es législations en cause poursuivaient un but justifié au regard du droit communautaire. ... [L] es effets restrictifs sur les échanges d'une réglementation nationale interdisant l'occupation de travailleurs salariés le dimanche ... n'apparaissent pas comme excessifs au regard du but poursuivi. La même constatation s'impose, pour les mêmes raisons, en ce qui concerne une réglementation nationale qui interdit aux commerces de détail d'ouvrir le dimanche. ${ }^{114}{ }_{»}$

Based on this observation, the Court of Justice concluded that Article 30 does not apply to national Sunday closing legislation. ${ }^{115}$

Although the reference in the Sunday Trading cases to the legislative objective and to the proportionality test confirms that the measures were considered to derogate from the principle of free intra-Community trade, one is left with the impression that the measures were acceptable not because of the

110. EC Commission, supra, note 41 at [1980] R.M.C. 514, Cassis de Dijon, supra, note 32 at para. 14; Marenco, supra, note 69 at 293; Defalque and Vandersanden, supra, note 8 at 94 , esp. text accompanying notes 123-29.

111. Indeed, many authors now simply refer to the derogation for exigences impératives as a «rule of reason», borrowing a term from U.S. and Community competition law. See Steiner, Textbook, supra, note 3; VerLoren van Themaat, supra, note 35 at 124.

112. Torfaen, supra, note 2 at 156.

113. See Conforama, supra, note 2 at I-1025 and Marchandise, supra, note 2 at I-1041.

114. Stoke-on-Trent, supra, note 2 at I-6659.

115. Ibid. at I-6660. 
imperative character of their objective but because of the absence of a compelling integrationist principle.

\section{B. Revival of the Theory of Disadvantage?}

I have argued that despite purporting to follow the reasoning introduced in Cassis de Dijon and Dassonville, the Court of Justice has emasculated the test of justification for exigences impératives. At the same time, however, an additional consideration has surreptitiously been introduced : in Cinéthèque and all four Sunday Trading cases, the Court of Justice began by observing that «the marketing of products imported from other member states was not ... made more difficult than the marketing of domestic products» by the legislation. ${ }^{116}$ Only after making this observation did the ECJ proceed to consider whether the objective was «a matter for the Member States» and proportionate to the «restrictive effects on intra-Community trade».

Although the Court of Justice does not explain in any of these judgments why the absence of discriminatory impact is relevant, it is certainly arguable that new life has been breathed into the theory of disadvantage. As I have pointed out, Marenco's theory had been widely rejected. ${ }^{117}$ The Court of Justice itself, mysteriously analyzing the non-discriminatory legislation in Cinéthèque under what everyone assumed was the Cassis de Dijon derogation (though without mentioning the term «exigences impératives» or Cassis de Dijon), appeared to have rejected it as well. Yet, if legislation not having a discriminatory impact is acceptable as long as it furthers (in a proportionate manner) an objective which is «a matter for the Member States», one would be forgiven for concluding that the Court of Justice has in effect embraced the «disadvantage» theory. The fact that non-discriminatory regulation is nevertheless branded by the ECJ as having «restrictive effects on intra-Community trade» is of little consequence if the regulation can be justified with no difficulty.

This is not to say that the situation following the Sunday Trading cases is satisfactory. In the first place, although both the Court of Justice and Marenco now agree that non-discriminatory national legislation which is disproportionate, even if it is enacted for a legitimate objective, may violate Article $30,{ }^{118}$ this proposition should be viewed with caution. In my opinion, the proportionality of a measure should not be considered unless the measure is prima facie a barrier to trade. If a measure is not formally discriminatory or discriminatory

116. Torfaen, supra, note 2 at 156; Conforama, supra, note 2 at I-1025; Marchandise, supra, note 2 at I-1040; Stoke-on-Trent, supra, note 2 at I-6657.

117. See supra, note 74 .

118. Marenco, supra, note 69 at 312 (in the case of regulations requiring a «manipulation of products»). 
in its effect, then its proportionality is a matter for domestic law, since disproportionate legislation which affects imports and domestic products equally does not result in geographic misallocation of production. It has of course been argued in Canada that a provincial measure infringes on the federal power over trade and commerce if its trade effects exceed those which are reasonably necessary for the attainment of its objective. ${ }^{119}$ However, I would point out that in the European Community, the impugned measures are those of sovereign States. The entire supra-national jurisdiction, including the ECJ, is a creation of the Member States. For this reason, Community institutions should be wary of evaluating the proportionality of national measures unless there is a threat to the free movement of goods.

A more important problem is that the Sunday Trading cases are merely the current stage of the sparsely reasoned «evolution» of the ECJ's jurisprudence on the derogation from the free movement of goods. Consequently, although in effect we have a new definition of the free movement of goods coinciding generally with that proposed by Marenco, it is unstable and is still perceived to relate to an exceptional derogation from a fundamental principle of the Common Market. ${ }^{120}$ Although the Stoke-on-Trent decision has definitively resolved the Sunday closing issue, the wording of the decision suggests that it is specific to the context of Sunday legislation. The Court of Justice does not indicate in Stoke-on-Trent that any new general principle has displaced Dassonville and Cassis de Dijon.

This objection may be substantially addressed by the Court of Justice's subsequent ruling in Keck and Mithouard. ${ }^{121}$ In a preliminary ruling issued late last year, the Court of Justice rules that Article 30 does not preclude national legislation prohibiting reselling at a loss, in spite of the fact that some of the products that might otherwise have been resold would have originated in other Member States. More importantly, the ECJ explains in its reasons that it is time to «reexamine and clarify» Cassis de Dijon; and that «contrary to what had previously been decided», indistinctly applicable and non-discriminatory restrictions on marketing are generally not susceptible of hindering intraCommunity trade. The Court of Justice's comments regarding its jurisprudence suggest that it finally recognizes that Cassis de Dijon cannot be taken at its face

119. See discussion supra, note 62 and accompanying text.

120. The confusion caused by the Sunday Trading cases is reflected in the House of Lords' decision in Stoke-on-Trent to refer the issue again to the ECJ, even though the Shops Act had already been considered by the Court of Justice, only 18 months earlier, in Torfaen. See the comments of the Advocate General in Case 306/88, Rochdale B.C. v. Anders, [1992] E.C.R. I-6457 at I-6464.

121. Cases C-267/91 and 268/91, Criminal Proceedings against B. Keck and D. Mithouard, unreported preliminary ruling issued 24 November 1993 (E.C.J.). 
(1993) 24 R.D.U.S.

Free Movement of Goods in the European Community :

A critique of the jurisprudence

value. I would argue that Keck and Mithouard eliminates the need to frame a defence of national legislation in terms of an exigence impérative or derogation from the principle of the free movement of goods. Legislation which meets the criteria proposed by Marenco will simply be presumed not to violate Article 30.

\section{Conclusion}

If the Court of Justice's jurisprudence on Article 30 has been unstable, it is in part because the «free movement of goods» is more a political slogan than a legal principle. ${ }^{122}$ Thus, idealistic pronouncements such as the Dassonville formula, combined with the enthusiastic adoption of the goal of harmonization in Cassis de Dijon, created the impression that all regulation was suspect. However, Article 30 did not authorize the Court of Justice to precipitate the harmonization of national laws simply by invalidating them. And even if the ECJ had wished to compel harmonization at the lowest common denominator, the Member States would surely have balked.

Unwilling to sacrifice its idealistic interpretation of Article 30, but lacking the authority to carry the interpretation to its logical conclusion, the Court of Justice turned to the derogation to trim the scope of Article 30. Starting with Cassis de Dijon, and continuing through Cinéthèque to the Sunday Trading cases, the derogation has been gradually relaxed. As well, through the evolution of the derogation, important criteria which had originally been rejected, such as non-discrimination and evenhanded application, were discreetly introduced.

As a result, the current scope of Article 30 is not unreasonable. Regrettably, however, the Court of Justice's lack of candour and, in particular, its failure to explain the status of Dassonville and Cassis de Dijon, have done little to reduce the uncertainty surrounding Article 30. Time may help to moderate the instability of the first two decades of jurisprudence on import restrictions, especially if the ECJ follows through its most recent decision, Keck and Mithouard. ${ }^{123}$ This case, it is hoped, will be taken as a signal from the Court of Justice that Cassis de Dijon must no longer be taken literally.

122. As observed by R.D. Lumb, commenting on s. 92 (the common market clause) of the Constitution of Australia, in The Constitution of Australia Annotated, 4th ed. (Sydney : Butterworths, 1986) at 307-308.

123. Supra, note 121 . 